\title{
Online Instructional Strategy with Different Goals Orientation on University Students' Higher Order Thinking Skills
}

\author{
Kasmudin Mustapa \\ Universitas Tadulako \\ Palu, Indonesia \\ kasmudinfkipuntad@gmail.com
}

\begin{abstract}
The rapid development of communication and computer technology bring a great impact on human life including education. The use of technology in every learning process has become a need, particularly in higher education level to produce a better teaching and learning process. This situation makes a vast contribution to the learning paradigm shift from a teacher-centered learning into a student-centered learning. The implementation of online instructional strategies is expected to enable students to overcome their learning problems, to encourage students' self-confidence and to perform their own independent learning. In this sense, students' characteristics such as their goal orientation and online instructional strategies will be one of the factors in the successful implementation of the improvement of higher order thinking skills in basic chemistry courses. The aims of this study are to examine the difference among students' higher order thinking skills using different goal orientation of learning and using goal orientation of performance. This study employed a quasi-experimental research design. The subjects were students of chemistry education (MIPA) at University of Tadulako Palu, Central Sulawesi, the instruments used in this study consisted of a written test, questionnaires, observation sheets, and an interview which is done before employing the instruments. The data were analyzed using ANOVA (Analysis of Variance). The research findings show that there are differences among students' higher order thinking skills taught using instructional goal orientation and those taught with performance goal orientation in basic chemistry courses, with a probability value of goal orientation is $0.029(<\alpha, 0.05)$, and the average of instructional goal orientation is 43.55 higher than the average of performance goal orientation which is $\mathbf{4 0 . 6 2}$,
\end{abstract} Skills.

Keywords-Online, Goal Orientation, Higher Order Thinking

\section{INTRODUCTION}

Communications and computer technology, a very rapid impact on human life, including in education. The definition of e-learning, it can be seen from the technology used and of the ongoing process of learning. According to [1] that the effectiveness of e-Learning was largely determined by how well the e-Learning is done when compared to traditional faceto-face teaching with the same content. E-learning can also be viewed as a type of learning that allows the teaching materials transfer to students by using the internet, intranet or other computer network media [2]. Further developments showed, online learning or e-learning, able to accommodate many of the participants, and not tied to a place and time as well as the active involvement of the learner are preferred. Results of the study of student interaction online learning, contributing heavily in the learning paradigm shift from teacher-centered learning (teacher-centered learning) into a student-centered learning (student-centered learning), the interaction is understood as a fundamental element in the learning environment [3]. The combination of a technology, coupled with a learning paradigm that focuses on the creation of knowledge and networking, offering the potential for a shift transformational in the practice of teaching and learning, in which learners can access peers, experts, the public, and digital media in a way that allows reflective, independent study [4].

Interactions can also be generalized to reflect the various stages of the mutual relationship, whether interpersonal or intrapersonal [5], [6]. Some research in online learning on student interaction with the learning environment, showing students who feel isolated in their learning environment, will have difficulty in obtaining their learning experience [7]. Instead, the learning experience is enriched with various means of interaction between students and the learning environment, will greatly assist students in conducting synthesis, evaluation, and application of science receive. based on responses provided, that the participants perceived online learning systems into web-instructional courses are effective; development and evaluation process did reveal some problems that need to be taken into account in the design of the full online version. Some of these issues relate to access, to design and others for learning styles. [8]. However, the ability to synthesize, evaluate and apply the knowledge possessed by the learners is very likely determined also by several other factors including models, methods, approaches and learning strategies, and a number of factors that also affect learning outcomes [9]. One such factor is the learning conditions. Learning conditions are defined as factors that influence the effect of the method in improving learning outcomes including interacting processes. Variables learning conditions are grouped into three groups, namely: (1) the purpose and characteristics of the field of study, (2) the constraints and characteristics of the field of study, and (3) the characteristics of learners. Characteristics of learners are aspects or qualities of individual learners, such as aptitude, interest, motivation, goal orientation, intelligence, cognitive styles, learning outcomes that have been owned, and others. Interrelations 
learning variables (methods, conditions, and outcomes) will give birth to a certain learning theory. Principles and theories of instructional design may be stated in either a descriptive or prescriptive form ". One of the characteristics of the teaching not yet widely known by teachers is a goal orientation, so rarely exposed in the scientific literature. Constructivist principles that include the concept of collaboration, interaction, and dialogue, in which the context and nature are learning is to consider negotiations, it has proven to be an important basis in developing a successful online learning community. Motivation has been identified as a key factor in developing and maintaining a sense of community as well as learning and achievement in the context of an online [10].

The subject of this research is the students who have the characteristics of the transition from the world of high school (learning to accept) to college (learning to think), so as to be able to understand and know the condition learn owned it is important to do research on the orientation of the aim shared by learners. Is the goal orientation refers to the desire to understand the chemistry or simply used as a springboard and just declare yourself as a student on a course of his choice? This is due to the orientation of interest explaining why students engage in learning activities. Individuals who have a belief that intelligence can evolve will tend to be oriented toward developing the intelligence (learning goal orientation). As said by Nicholls in [9], that the orientation of each individual learner objectives with regard to their beliefs about the causes of success and would become a common standard rating success. While Dweck in [9], says that the goal orientation is the basic nature of intelligence is defined as the perception of the learners about the ability and intelligence to change from time to time.

One area of IPA is a chemical that has an essential role in the development of science and technology. Chemistry is a basic science that supports the development of science and technology. The chemistry includes materials of diverse and includes facts, concepts, rules, laws, principles, theories and problems [11]. In this regard, the purpose of chemistry teaching is to gain an understanding of durable concerning the facts, the ability to think, the ability to recognize and solve problems, skills in using tools and materials laboratories, as well as having a scientific attitude that can be displayed in reality daily. Chemistry is a part of natural science (IPA), which is not easy to be defined as the extent of the field being studied. The chemistry does not just solve problems, but also learn the description of chemical facts, special terminology, and rules of chemistry, to the higher concept. For most students, chemistry is one of the difficult material. The level of difficulty in studying chemistry caused by the characteristics of chemistry itself, namely: (1) the majority of chemical concepts are abstract; (2) chemistry is the simplification of previous circumstances; (3) The sequential nature of chemical materials and growing fast; (4) the chemistry is not just solving problems; (5) the material to be learned in chemistry very much. Ref. [12] reported in a study that the chemical, including a difficult lesson. Ref. [13] said that the adjustability of online learning for subjects theoretically or practically, initially felt that the subject could be in the best theory online condition while teaching practical subjects are best delivered in a teaching situation face to face.

Most of the concepts of chemistry have properties of high abstraction because chemistry is the science submicroscopic [14]. Abstract nature is what led to the conception of chemistry is difficult in construction or wrongly constructed by learners (misconception) that require the ability to analyze (C4), synthesizing (C5) and evaluate (C6) every problem. The essence of chemistry is a product, process, and gave birth to a scientific attitude. According to [15] that the development of effective instructional practices using PRS or interactive technologies in teaching chemistry course has significant potential to advance the understanding of education. This condition reflects the birth of chemistry problem-solving ability is one of the high-level thinking skills. High-level thinking skills will happen when someone, where new information with information already stored in memory and will connect or rearrange and develop the information to achieve a goal or to find the solution of a difficult situation, solved [16]. If the low-level learners the ability to think both the high-level thinking skills will also be good or otherwise. So the correlation between low and high-level thinking can show how far learners understand concepts in chemistry. The packaging of adult learning is often based on assumptions that are not in line with the nature of learning, the nature of the learning, and the nature of those who teach. Paradigm arcing involves only information which low-level thinking skills to encourage learners on rote learning (rote learning style). Ref. [17] states "... rote learning leads to inert knowledge we know something but never apply it to real life". Ref. [18], stated learners who have high-level thinking skills (higher order thinking skills) were able to distinguish between fact and opinion, identifying relevant information, solve problems, and is able to infer information that has been the analysis. The availability of technology, educational software and applications become easy and available outside to help teachers and students to learn and to obtain information online. All of this is intended to help students to learn better and have more understanding of what they want to accomplish [19].

The successful implementation of the process of high-level thinking skills development today requires thoughtful consideration of instructional techniques and active commitment to the environment centered on learners. This condition makes it possible to involve the learners in a large group with the pattern of online interactions so that all can be resolved in the perspective of solving problems / questions, their thinking skills high level (higher order thinking skills) will make somebody (learners) are able to look at something (events, objects, facts) more carefully so as to determine the attitudes of the incident with the decision to be taken based on a thorough consideration. Research on student attitude and participation in interactive discussions via the web, or online interaction have been implemented, among others by [20], [21], and also in learning cooperatively [22], reported that interactive learning online can increase student participation and also enhance the problem-solving. According to Osborne $\&$ Wittrock in [11] that the students before getting the subject matter of the school, has had a conception or ideas about 
natural events, but most of these conceptions still as an everyday knowledge that scientific knowledge has not shown. This can also apply to students who enter the world of world universities in basic chemistry courses. Basic Chemistry subjects are subjects that must be followed by a chemistry student because this course is a prerequisite for the course of study fields of chemistry in subsequent semesters. The process of online learning is expected to maximize the process of discussion with the characteristics of the study chemical materials that are procedural, symbolic and narrative, and supported by a variety of reading materials or information through the website to be able to push the level of interest in analyzing, synthesizing and evaluate each study chemical materials contained with a variety of instructional design through video, animation and powerpoint. But in every teaching situation, the role of educators in the online system are important in ensuring effective learning outcomes. To be effective, teachers need more than technical competence. They need to have an understanding of the dynamics of online communication and interaction and need to learn effective ways to facilitate and teach online [23].

Based on the above, the research objectives to be achieved are: To examine differences in thinking skills that have a high level of student learning goal orientation and performance goal orientation with the implementation of online strategies in basic chemistry courses.

\section{METHOD}

This study uses a quantitative approach (quantitative research), the type of study design used was the quasi experiment (quasi-experimental). An experimental design using a nonequivalent control group pretest-posttest design, version $2 \times 2$ factorial were analyzed by ANOVA technique. [24]. The variables used in this study as follows: the independent variable is an online learning strategy and expository, the moderator variables in learning goal orientation and appearance, and the dependent variable is the high-level thinking skills (higher order thinking abilities/HOTA). The subjects are chemistry education students FKIP Tadulako totaling 57 experimental class and the control class of 55 people. The instrument used in this study consisted of: (1) a written test sheet measuring high-level thinking skills (higher order thinking abilities/HOTA); (2) copies of the questionnaire to measure the inclination student goal-oriented, good learning goal orientation and performance goal orientation. Adapting this questionnaire goal orientation of [25]. Results descriptive high-level thinking skills (higher order thinking abilities/HOTA) to calculate a percentage. Ref. [26] The process to determine the classification of goal orientation of students (learning or performance) performed by determining the median of goal orientation questionnaire data in each treatment group. The use of e-learning as an online media for the process of learning interactions [27].

\section{RESULTS AND DISCUSSION}

\section{A. Research Hypothesis Testing}

Hypothesis testing research data were analyzed by analysis of variance of two lanes $2 \times 2$. The results of the analysis by the independent variable learning strategies and goal orientation and the dependent variable high-level thinking skills of students are presented in Table I below.

TABLE I. VARIANT ANALYSIS RESULTS FROM TwO LINE 2 X 2

\begin{tabular}{|c|c|c|c|c|c|}
\hline \multicolumn{7}{|c|}{$\begin{array}{c}\text { Dependent Variable: } \\
\text { High-Level Thinking Skills }\end{array}$} \\
\hline Source & $\begin{array}{c}\text { Type III Sum of } \\
\text { Squares }\end{array}$ & $d f$ & Mean Square & $\boldsymbol{F}$ & Sig. \\
\hline $\begin{array}{c}\text { Corrected } \\
\text { Models }\end{array}$ & $1507.715 \mathrm{a}$ & 3 & 502.572 & 7.941 & .000 \\
\hline Intercept & 197925.965 & 1 & 197925.965 & 3.1273 & .000 \\
\hline $\begin{array}{c}\text { Strategies } \\
(\mathrm{X} 1)\end{array}$ & 990.285 & 1 & 990.285 & 15.648 & .000 \\
\hline $\begin{array}{c}\text { Orientation/ } \\
\text { OT(X2) }\end{array}$ & 492.375 & 1 & 492.375 & 7.780 & .006 \\
\hline $\begin{array}{c}\text { Strategies } \\
(\mathrm{X} 1)^{*} \text { OT } \\
(\mathrm{X} 2)\end{array}$ & 53.870 & 1 & 53.870 & .851 & .358 \\
\hline Error & 6834.880 & 108 & 63.286 & & \\
\hline Totals & 208468.219 & 112 & & & \\
\hline $\begin{array}{c}\text { Corrected } \\
\text { Totals }\end{array}$ & 8342.595 & 111 & & & \\
\hline \multicolumn{7}{|c|}{ a. R Squared $=.155$ (Adjusted R Squared =.132) } \\
\hline
\end{tabular}

Results of analysis of variance of two lanes $2 \times 2$ in Table I obtained probability value learning strategy that is $0.000(<\alpha$ 0.05 ), so the null hypothesis (Ho) refused and accept alternative hypothesis (H1). This means that "there are different high-level thinking skills of students in the given treatment with online learning in basic chemistry courses". To determine the learning strategies that provide a better effect, it can be seen in the average (mean) of descriptive statistics in Table II.

TABle II. VARIANT ANALysis DESCRIPTIVE StATISTICS DESCRIPTIVE STATISTICS TWO PATHS

Dependent Variable: High-Level Thinking Skills

\begin{tabular}{|c|c|c|c|c|}
\hline $\begin{array}{c}\text { Learning } \\
\text { strategies }\end{array}$ & $\begin{array}{c}\text { Orientation } \\
\text { Objectives }\end{array}$ & Mean & $\begin{array}{c}\text { Std. } \\
\text { Deviation }\end{array}$ & N \\
\hline \multirow{2}{*}{ Online } & Study & 46.49 & 7.754 & 30 \\
\cline { 2 - 5 } & Appearance & 43.68 & 8.457 & 27 \\
\cline { 2 - 5 } & Totals & 45.16 & 8.145 & 57 \\
\hline \multirow{2}{*}{ Totals } & Study & 44.24 & 8.083 & 59 \\
\cline { 2 - 5 } & Appearance & 40.07 & 8.845 & 53 \\
\cline { 2 - 5 } & Totals & 42.27 & 8.669 & 112 \\
\hline
\end{tabular}

Based on Table 4.1 in the known value the probability of goal orientation that is $0.006(<\alpha 0.05)$, so the null hypothesis (Ho) is rejected and accept the alternative hypothesis (H1). This shows "there are differences in thinking skills that have a high level of student learning goal orientation and performance goal orientation on basic chemistry courses", then the table 4.2 Unknown 44.24 average learning goal orientation and performance goal orientation average of 40.07. Learning goal 
orientation mean higher than average performance goal orientation.

\section{B. Discussion}

Based on Table 4.1 can know the probability value orientation of the goal of $0006(<\alpha 0.05)$ so that the null hypothesis is rejected and accept the alternative hypothesis. This shows that "there are differences in thinking skills that have a high level of student learning goal orientation and performance goal orientation on basic chemistry courses", so from Table 4.2 can be in the know that the average learning goal orientation is 44.24 and the mean performance goal orientation is 40.07 . Learning goal orientation mean higher than average performance goal orientation so that it can be said that learning goal orientation provides a better effect on high-level thinking skills of students than the appearance of goal orientation.

The success of a learner in learning not only be viewed from one aspect, because it allows us there are various factors that cause a failure learners in learning. In addition to the learning strategy, there are a number of factors that also affect learning outcomes. A university teaching process is carried out shared among faculty, which is attributable, students can be exposed to a variety of learning experiences for different interpretations of the subject content and teaching styles are different. It is often confusing for students so that strived to provide consistency, an online recording of the lectures and tutorials posted on WebCT [28]. One such factor is the learning conditions. Learning conditions one of which is characteristic of learners such as goal orientation. For the goal orientation with regard to a person's cognitive processes that explain why learners are involved in a variety of learning activities. As noted by Schunk et al, (2008), that the theory of goal orientation suggests there are two general orientations that can be adapted by the students in achieving academic tasks they are: the orientation of mastery which focuses on learning and mastery of course content and performance orientation that focuses on show the ability, get a good academic grades or awards, or outperformed other participants. Many researchers have investigated the relationship between learning goal orientation and performance with outcomes such as the level of information search, cognitive engagement, self-learning, persistence, and appearance. Most have agreed that in general the learning outcomes that can adjust to being associated with learning goal orientation, otherwise learning outcomes are less able to adjust the orientation associated with performance goals.

Results of research [29], describes the intrinsic motivation, component troubleshooting, and correlations among the variables associated with the orientation of learning objectives, their findings include the students in the context of learning orientation is significantly scores intrinsic motivation is higher than the in the context of the orientation of the appearance, in terms of problem-solving ability, the mean score heterogeneous group was higher than homogeneous groups, particularly in monitoring and evaluating the solution, and the results showed a positive correlation between goal orientation and problem-solving among the variables associated with goal orientation learning (learning goal orientation). Use of the task is challenging, meaningful, and in touch with the real world is more likely to lead to the learning objectives than other tasks [30]. These findings were also confirmed by the results of interviews on several representative respondents and found that the learningoriented individuals are more likely to look for a challenging situation and seeing ability as something that can be determined and under their control. They tend to use themselves and their past performances as a reference to measure their success, against self-reliance on social comparison and reacted positively experience failure. Failure is seen as an opportunity to get progress. Performanceoriented individuals, on the other hand, pay attention to the positive acquisition or avoid the negative evaluation of their performances, and community-oriented. They reacted negatively because they see failure as something constant ability and failure is evidence of the weakness of their ability. Usually in situations where low perceived ability, appearanceoriented individuals are more likely to leave a chance to improve their level of ability. Results of research conducted by [31], suggesting that the presence and proximity of teaching can affect cognitive and attitude learning experience of students. This has implications for professional training in online teaching and learning for educators in general.

Mean score obtained from the implementation of the pretest and posttest scores include high-level thinking skills / high order thinking abilities (HOTA) students before and after treatment. HOTA total value obtained by the average value of multiple choice questions and problem descriptions. Results of $2 \times 2$ factorial analysis of variance in Table 4.1, the value of the probability of a learning strategy that is $0.000(<\alpha 0.05)$, so the null hypothesis is rejected and accept the alternative hypothesis. This means that "there are high-level thinking skills of students in the given treatment with online learning in basic chemistry courses". In Table 4.2 shows that the total average posttest high-level thinking skills of students in the given treatment online learning strategies 45.16. Mean posttest online learning is higher than the average posttest learning. This suggests that online learning strategy gives a better effect on high-level thinking skills of students in the subject of basic chemistry. It also means that teachers should be given more knowledge and an explanation of how to instill HOTS. Therefore it is necessary for the teacher training program involves planting HOTS. This preliminary study also shows that there is a need to explore further what teachers do in the classroom to see whether or not HOTS being implanted. It is important to ensure that the government's efforts to produce creative and critical thinking will be successful in the long term [32]. Teachers should be aware that HOT teaching effectiveness will be realized only if the traditional view became a more constructivist view of learning process [33].

If the study results are used as a gauge to determine the effectiveness of study, the results of this study are also consistent with several previous studies, [34] said that online learning gives a higher impact than learning using student's worksheet toward chemistry learning achievement. [13] who conducted a meta-analysis of the empirical literature on the comparative study of 160 distance learning (online) and traditionally among the 1985-2002 concluded that on average 
learning of interactive distance education achievements gained about $10 \%$ higher than on reaching an average of learners in a traditional classroom.

Another study [35] said that the implementation of this flexible teaching model (online) including successful when viewed from the standpoint of technology as learners will have high self-confidence and have the ability to direct their own learning. The presence of the Internet as access to learning has many advantages that learners can obtain information and knowledge as well as create a learning environment that has wider coverage without being limited by space and time, as well as the creation of a learning environment that is more open in regard to sustain and encourage the process of learning [36], Differences in high-level thinking skills of students in the output of this research is due because inside every respondent has stored an initial understanding that would be associated with a new understanding. Because according to Osbome \& Wittrock in [11], the student before getting the subject matter of the school, has had a conception or ideas about natural events, but most of these conceptions still as the everyday knowledge that scientific knowledge has not shown. According to [16], high-level thinking skills will happen when someone where new information with existing information stored in the memory and connector rearrange and develop the information to achieve a goal or to the bottom of a condition which is difficult to solve.

The yield difference is also due to the application of learning strategies Online learning is very efficient because it eliminates the distance between the students with a place to learn. The distance can be eliminated because the contents of the e-learning / online design with media such that it can be accessed from a computer terminal that has the appropriate equipment and other technological means to access a network or the Internet. It is likewise that by [37], stated that online education has become a central element in the discussion in the college, for online delivery of teaching methods is considered advantageous.

Results of the study of student interaction online learning to provide a huge contribution in the learning paradigm shift from teacher-centered learning (teacher-centered learning) into a student-centered learning (student-centered learning), the interaction is understood as a fundamental element in the learning environment. According to [34], that the results of the analysis indicate there are four main considerations when designing e-learning and online courses: 1) the structure of the program, 2) presentation of content, 3) collaboration and interaction, and 4) timely feedback. The birth of the computer as a means of interaction between users either synchronously or asynchronously (ie email, online discussion forums and chat), if combined with online learning management via the LMS, is believed to be one powerful way to improve the quality of online learning. Based on this knowledge, in future work, the proposed approach will be extended so that it will incorporate also the profile of teachers, providing a view of bilateral of the role of active input of LMS, namely, teachers and students, to a more interactive, adaptable, and environmental learning co-participatory. [38], [39].
Several other research in online learning on student interaction with the learning environment, showing students who feel isolated in their learning environment, will have difficulty in obtaining their learning experience [37]. Instead, the learning experience is enriched with various means of interaction between students and the learning environment, will greatly assist students in conducting synthesis, evaluation and application of science received [35]. So hope through online learning model, students are able to take the initiative, overcoming obstacles or problems in learning, have confidence and can make the process of learning independently. As an educator, this study aims to help students to think deeply about the content and potentially use this information to guide their future thoughts and actions [40].

Electronic learning (online learning) is a learning activity that utilizes a network (Internet, LAN, WAN) as a medium for the delivery, interaction, and facilities, and supported by various other forms of learning services. Use of LAN, WAN, Internet for educational purposes is increasingly widespread, especially in developed countries, a fact which indicates that the media is made possible through the convening of the learning process more effective. It happened because of the nature and characteristics of the Internet network which is fairly typical, so it is expected to be used as a medium of learning as well as other media that have been used previously such as radio, television, CD-ROMs and other iterative. Research on student attitude and participation in interactive discussions via the web or online interaction have been implemented, among others by [4], [20], [21], and also in learning cooperatively [41], reported that learning online can increase student participation and enhance the problemsolving. The literature study also showed that the success of using online resources for student development of critical thinking in the context of HE least partly dependent on the level of development of students, their experience with the technology used in academic settings and the level of their involvement. successful learning about critical thinking in the online environment also depends on the quality of online resources and tools. This case study shows that many students find online learning on critical thinking to help, stimulate and attractability [42]. It can provide students with technical experience to broaden their perspectives on critical thinking through the network in the institutional environment and cross-broader cross country.

The implementation of online learning mechanism that will be carried out, students are expected to collaborate with all potential learning resources in the form of teaching materials, powerpoint, animation, video, other students, faculty, and others. One of the prominent features of online teaching and learning process is the student as the subject of active, independent learning, and teachers act as facilitators or learning partners. According to [43], that there are two main things in the learning technology is an important technology in terms of results and technology can be used to make a difference when evaluating educational outcomes. Online learning mechanism that is done in the hope students can collaborate with all potential learning resources in the form of teaching materials, powerpoint, animation, video, other students, faculty, and others. Online learning provides a higher 
impact than learning using student's worksheet toward chemistry learning achievement. Because these learning resources can bridge the increased knowledge of learners. The concept and the provision of a practical exercise that leads to proving the hypothesis by giving some facts between changing one fact to another fact, will make the learners can create his own hypothesis [43], that the factors which affect online interaction, including the size of the study group, another participant knowledge related to learning content and learning experiences for clarity level of individual interaction. The lack of interaction in online learning poses serious obstacles to the performance of learning for meaningful interactions contribute to the learning outcomes in educational contexts. interactive learning environment enables instructors to predetermine and organize the learning content is suitable for a given environment before giving instructions with a view to enhancing the learning experience. Based on critical analysis and gaps made by [44], that is identified, any proof design information ET intervention should be based on a better conceptualization of the forms of learning and how interventions can be integrated into the context of the implementation, which is focused on technology as an agent of change. The online learning process has been done at various universities. It is also described by [37], that institutions throughout the country have been doing their bidding against online programs, hybrid, and class. The flexibility and convenience of these programs a lot more people have the opportunity to achieve their goals in the development while increasing the level of potential revenue for educational institutions.

\section{CONCLUSION}

The conclusion of this study was: Based on the results of the study concluded that; there are differences in thinking skills that have a high level of student learning goal orientation and performance goal orientation with the adoption of online learning strategies in basic chemistry courses.

\section{REFERENCES}

[1] R. Noesgaard, Signe Schack, Ørngreen, "The Effectiveness of ELearning: An Explorative and Integrative Review of the Definitions, Methodologies, and Factors that Promote e-Learning Effectiveness," Electron. J. e-Learn., vol. 13, no. 4, pp. 278-290, 2015.

[2] O. Oludare Jethro, A. Moradeke Grace, and A. Kolawole Thomas, "ELearning and Its Effects on Teaching and Learning in a Global Age," Int. J. Acad. Res. Bus. Soc. Sci., vol. 2, no. 1, pp. 2222-6990, 2012.

[3] C. Juwah, "Interactions in Online Education," Interact. Online Educ. Implicit. Theory Pract., vol. 10, pp. 1-256, 2006.

[4] C. Mcloughlin and M. J. W. Lee, "The Three P' 's of Pedagogy for the Networked Society: Personalization, Participation, and Productivity," Int. J. Teach. Learn. High. Educ., vol. 20, no. 1, pp. 10-27, 2008.

[5] A. Hirumi, "Analysing and designing e-learning interaction," in Analysing and designing e-learning interaction, vol. 3, no. 0, C. Juwah, Ed. New York: Routledge, 2000, pp. 47-69.

[6] S. Mayes, T. and de Freitas, Review of e-learning theories, frameworks and models: JISC e-Learning Models Desk Study, no. September. version deposited in CURVE, 2013.

[7] T. Pham, V. Thalathoti, and E. Dakich, "Frequency and pattern of learner-instructor interaction in an online English language learning environment in Vietnam," Australas. J. Educ. Technol., vol. 30, no. 6, pp. 686-698, 2014.
[8] V. Vonganusith and P. Jeremy, "Web-based Courses to Support EFL Learning for Pre-service Teachers: A Thai Pilot Study," in Conferences, Symposia and Campus Events, 2008, no. November, pp. 19-21.

[9] Eggen, P \& Kauchak, D. Strategic and Models for Teaching Content and Thinking Skills, Sixth Edition (Eds): Boston. Perason Education, Inc. 2012.

[10]M. Hartnett, Motivation in Online Education: The Importance of Motivation in Online Learning, DOI 10.100., no. 2. Singapore: Springer Science+Business, 2016.

[11]K. Mustapa, "Seminar Nasional Kimia dan Pembelajarannya," 2015.

[12]G. D. Chittleborough, D. F. Treagust, and M. Mocerino, Constraints to the development of first-year university chemistry students ' mental models of chemical phenomena, no. 0. Teaching and Learning Forum $2002,2002$.

[13]R. Chew and S. Yee, "PERCEPTIONS OF ONLINE LEARNING IN AN AUSTRALIAN UNIVERSITY: MALAYSIAN STUDENTS PERSPECTIVES," in Centre for Learning Innovation Faculty of Education Queensland University of Technology, 2011, pp. 1-283.

[14]K. K. Bhagat, L. Y. Wu, and C. Y. Chang, "Development and validation of the perception of students towards online learning (POSTOL)," Educ. Technol. Soc., vol. 19, no. 1, pp. 350-359, 2016.

[15]T. Chen and Y. Lan, "Using a personal response system as an in-class assessment tool in the teaching of basic college chemistry," Australas. $J$. Educ. Technol., vol. 29, no. 1, pp. 32-40, 2013.

[16]Fadjar Shadiq, "Kemampuan Menentukan Kebijakan ( Judgment Skill ). Kemampuan Memecahkan Masalah ( Problem Solving Skill). Kemampuan Dalam Pengambilan Keputusan ( Decision Making Skill). Kemampuan Kewirausahaan ( Entrepreneurship ). person takes new information and info," 2007.

[17]Smaldino, S. E., Russell, J.D., Heinich. R \& Molenda, Instructional Technology and Media for Learning (Eighth Edition). Columbus, Ohio: Pearson Merrill Prentice Hall, 2005.

[18] A. E. Woolfolk-hoy and A. Woolfolk, EDUCATIONAL PSYCHOLOGY: ACTIVE LEARNING EDITION, 9th ed. Boston: Pearson Allyn \& Bacon, 2005.

[19]F. Mantiri, "Multimedia and Technology in Learning," Univers. J. Educ. Res., vol. 2, no. 9, pp. 589-592, 2014.

[20]G. Wilson and E. Stacey, "Online interaction impacts on learning: Teaching the teachers to teach online," Australas. Journal Educ. on Technol. Technol., vol. 20, no. 1, 2009.

[21]M. Thorpe, "Effective online interaction: mapping course design to bridge from research to practice," Australas. J. Educ. Technol., vol. 24, no. 1, pp. 57-72, 2008.

[22]M. Neo, "Cooperative learning on the web: A group based, studentcentered learning experience in the Malaysian classroom Introduction: Using ICT in teaching and learning Cooperative learning: The pedagogical perspective," Australas. J. Educ. Technol., vol. 20, no. 2, pp. $171-190,2004$

[23] S. O. Hare, "The Role of the Tutor in Online Learning," in Ascilite, 2011, pp. 909-918.

[24]B. W. Tuckman and A. W. Urquhart, Conducting Educational Research, Fifth Edit. Toronto Montreal London Sydney Tokyo: Harcourt Brace College Publishers, 1999.

[25]D. E. Swartz, "GOAL ORIENTATION AND TRAINING TRANSFER INITIATION AND MAINTENANCE," Faculty of the Virginia Polytechnic Institute and State University in, 2002.

[26]Lewy, Zulkardi, and N. Aisyah, "Pengembangan soal untuk mengukur kemampuan berpikir tingkat tinggi pokok bahasan barisan dan deret bilangan di kelas ix akselerasi SMP xaverius maria palembang," $J$. Pendidik. Mat., vol. 3, no. 2, 2009.

[27] Beatrice Ghirardini, E-learning methodologies: A guide for designing and developing e-learning courses. Germany: Food and Agriculture Organization of the United Nations, 2011.

[28]L. Wong, "Student Engagement with Online Resources and Its Impact on Learning Outcomes," J. Inf. Technol. Educ. Innov. Pract., vol. 12, 2013.

[29]Song, H. D \& Grabowski, B. L. Stimulating intrinsic motivation for problem solving using goal-oriented contexts and peer group composition. Educational Technology Research \& Development Journal., vol.54, no. 5, pp. 445-466. 2006.

[30]R. E. Slavin, Educational Psychology: Theory and Practice. Boston: Allyn and Bacon, 2000.

[31] Misha Chakraborty and Fredrick Muyia Nafukho, "Strategies for Virtual 
Learning Environments: Focusing on Teaching Presence and Teaching Immediacy," Internet Learn., vol. 4, no. 1, pp. 1-37, 2015.

[32]M. Y. Kamarudin, N. Mohd, R. Nik, and H. Y. Ahmad, "Inculcation of Higher Order Thinking Skills ( HOTS ) in Arabic Language Teaching at Malaysian Primary Schools," Creat. Educ., vol. 7, no. February, pp. 307314, 2016.

[33]T. S. Yen and S. H. Halili, "EFFECTIVE TEACHING OF HIGHERORDER THINKING (HOT) IN EDUCATION," Online J. Distance Educ. e-Learning, vol. 3, no. 2, pp. 41-47, 2015.

[34]M. Lister, "Trends in the Design of E-Learning and Online Learning," MERLOT J. Online Learn. Teach., vol. 10, no. 4, pp. 671-680, 2014.

[35]E. Johnson Marcia, B. Cowie, W. De Lange, G. Falloon, C. Hight, and E. Khoo, "Adoption of innovative e-learning support for teaching: A multiple case study at the University of Waikato," Australas. J. Educ. Technol., vol. 27, no. 3, pp. 499-513, 2011.

[36]H. Kipper and T. Rüütmann, "Contemporary Teaching Strategies and Models Capacitating Critical Thinking and Deep Understanding in Teaching Engineering," in Joint International IGIP-SEFI Annual Conference, 2010, no. September, pp. 19-22.

[37]H. H. Friedman and L. W. Friedman, "Crises in Education: Online Learning as a Solution," Creat. Educ., vol. 2, no. 3, pp. 156-163, 2011.

[38] S. B. Dias and J. A. Diniz, "Towards an Enhanced Learning Management System for Blended Learning in High," Educ. Technol. Soc., vol. 17, no. 10, pp. 307-319, 2014.

[39]J. F. Rhode, "Learning Environments: An Exploration of Learner Preferences," Int. Rev. Res. Open Distance Learn., vol. 10, no. 1, 2009.

[40]J. Thormann and P. Fidalgo, "Guidelines for Online Course Moderation and Community Building from a Student's Perspective," MERLOT J. Online Learn. Teach., vol. 10, no. 3, pp. 374-388, 2014.

[41]N. Edmond and M. Hayler, "Journal of Education for Teaching: International research and pedagogy On either side of the teacher: perspectives on professionalism in education," J. Educ. Teach. Int. Res. Pedagog., vol. 39, no. 2, pp. 209-221, 2013.

[42]E. Carmichael and H. Farrell, "Evaluation of the Effectiveness of Online Resources in Developing Student Critical Thinking: Review of Literature and Case Study of a Critical Thinking Online Site," J. Univ. Teach. Learn. Pract. Vol., vol. 9, no. 1, pp. 1-19, 2012.

[43]C. Clem and and R. Junco, The Wiley Handbook of Psychology, Technology, and Society: The Future of Technology in Education, First Edit. John Wiley \& Sons, Ltd, 2015.

[44]L. Price and A. Kirkwood, "Informed design of educational technology for teaching and learning? Towards an evidence-informed model of good practice," Technol. Pedagog. Educ., vol. 5139, no. June 2015, pp. 1-23, 2014. 